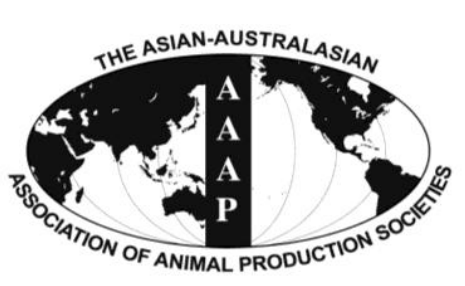

Open Access

Asian Australas. J. Anim. Sci.

Vol. 27, No. 5 : 757-766 May 2014

http://dx.doi.org/10.5713/ajas.2012.12524

www.ajas.info

pISSN 1011-2367 elSSN 1976-5517

\title{
Historical Overview of the Effect of $\beta$-Adrenergic Agonists on Beef Cattle Production
}

\author{
Bradley J. Johnson, Stephen B. Smith ${ }^{1}$, and Ki Yong Chung ${ }^{2 \text {,* }}$ \\ Department of Animal and Food Sciences, Texas Tech University, Lubbock 79409, USA
}

\begin{abstract}
Postnatal muscle hypertrophy of beef cattle is the result of enhanced myofibrillar protein synthesis and reduced protein turnover. Skeletal muscle hypertrophy has been studied in cattle fed $\beta$-adrenergic agonists $(\beta$-AA), which are receptor-mediated enhancers of protein synthesis and inhibitors of protein degradation. Feeding $\beta$-AA to beef cattle increases longissimus muscle crosssectional area $6 \%$ to $40 \%$ compared to non-treated cattle. The $\beta$-AA have been reported to improve live animal performance, including average daily gain, feed efficiency, hot carcass weight, and dressing percentage. Treatment with $\beta$-AA increased mRNA concentration of the $\beta_{2}$ or $\beta_{1}$-adrenergic receptor and myosin heavy chain IIX in bovine skeletal muscle tissue. This review will examine the effects of skeletal muscle and adipose development with $\beta$-AA, and will interpret how the use of $\beta$-AA affects performance, body composition, and growth in beef cattle. (Key Words: $\beta$-Adrenergic Agonists, Skeletal Muscle, Beef Cattle)
\end{abstract}

\section{INTRODUCTION}

Increasing lean yield, i.e., muscle mass, while also increasing feed efficiency would greatly benefit the beef cattle industry. One unique physiological characteristic of skeletal muscle tissue compared to other tissues is that the number of multinucleated cellular units, muscle fibers, is fixed at birth. This obviates hyperplastic growth as a means of increasing muscle mass, so increasing muscle hypotrophy has been a primary focus of research scientists at universities, government agencies, and pharmaceutical companies. Post-mitotic growth of muscle is achieved through either DNA accumulation or through increasing the ratio of protein to DNA in muscle fibers. Whereas steroidal implants tend to increase muscle mass by increasing the accumulation of DNA in muscle, beta-adrenergic agonists

\footnotetext{
* Corresponding Author: Ki Yong Chung. Tel: + 82-33-330-0613 Fax: +82-33-330-0660, E-mail: cky95@korea.kr

${ }^{1}$ Department of Animal Science, Texas A\&M University, College Station 77843, USA.

${ }^{2}$ Hanwoo Experiment Station, National Institute of Animal Science, RDA, Pyeongchang 232-950, Korea.

Submitted Sept. 20, 2012; Revised Dec. 27, 2012; Accepted Mar. 12, 2014
}

$(\beta$-AA) increase muscle mass by increasing the ratio of protein to DNA (Walker et al., 2010), similar to effects seen with the administration of somatotropin to beef cattle (Vann et al., 1998). Steroidal implants and $\beta$-adrenergic receptors ( $\beta$-AR), commonly used in the North and South American cattle industries, have similar physiological responses of muscle hypertrophy, appear to have different mechanisms of action to achieve muscle growth, but the mode of action of $\beta$-AA in beef cattle is still not fully understood. Even less is known about the mechanisms by which $\beta$-AA depress adipose accretion in livestock species. This review will focus primarily on the biology of $\beta$-AA as it relates to lipid metabolism in adipose tissue and protein metabolism in skeletal muscle of livestock species.

\section{PHYSIOLOGICAL FUNCTION OF $\beta$-ADRENERGIC AGONISTS}

The $\alpha$-adrenergic receptor $(\alpha-\mathrm{AR})$ and the $\beta$-AR are members of a large superfamily of $\mathrm{G}$ protein-coupled receptors (GPCR). Previous articles by Mersmann and coworkers have provided an overview of $\beta$-AR biology in livestock species, although these articles focused primarily

Copyright @ 2014 by Asian-Australasian Journal of Animal Sciences This is an open-access article distributed under the terms of the Creative Commons Attribution Non-Commercial License (http://creativecommons.org/licenses/by-nc/3.0/), which permits unrestricted non-commercial use, distribution, and reproduction in any medium, provided the original work is properly cited. 


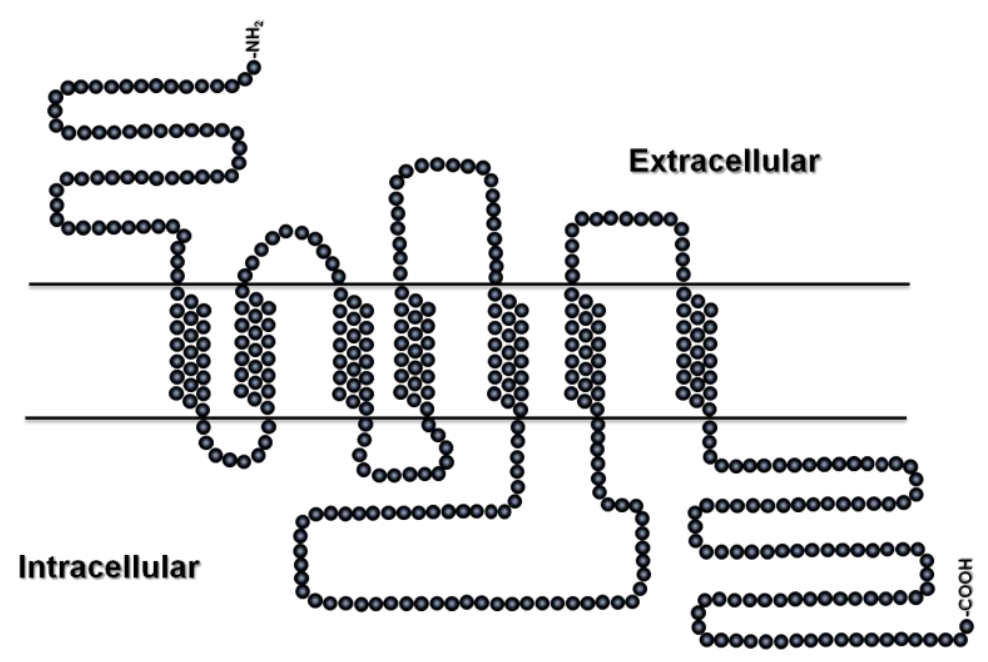

Figure 1. Model of the $\beta_{2}$-adrenergic receptor.

on adipose tissue metabolism in swine (Mills and Mersmann, 1995; Mersmann, 1998; Mersmann and Smith, 2005). All $\beta$-AR contain seven hydrophobic, transmembrane domains (Figure 1). The $\beta$-AR are part of a large family of GPCR, which arose from a common ancestral gene, and were modified to accommodate a wide variety of ligands (Mills and Mersmann 1995). The homology among the receptors is approximately 50\%, whereas across species, the homology is $>75 \%$ within a subtype.

In general, $\beta$-ARs consist of over 400 amino acids. Each $\beta$-AR contains three extracellular segments associated with the N-terminus and three intracellular loops with the Cterminus (Mills and Mersmann, 1995). Binding of the signal transduction elements occurs at intracellular loop 3 in the G-proteins, whereas the regulatory phosphorylation sites are located at the C-terminal. Phosphorylation at loop 3 leads in inactivation of the C. Ricks et al. (1984) proposed that $\beta$-AA reduce adipose tissue accretion by the combined effects of inhibiting de novo fatty acid biosynthesis and concurrently stimulating triacylglycerol (TAG) hydrolysis, or lipolysis (Figure 2). Conversely, muscle mass is increased by inhibiting protein turnover and promoting myofibrillar protein synthesis. The biological reactions of $\beta$-AA occur in peripheral tissues or cells that express $\beta$-AR. Most of the actions of $\beta$-AA can be attributed to an elevation of cAMP, as interaction of $\beta$-AA with $\beta$-AR stimulates adenylate cyclase via the stimulatory $\mathrm{G}_{\mathrm{s}}$-protein system (Figure 3). Once the concentration of cAMP is increased, it binds to the regulatory subunits of protein kinase A, which phosphorylates serine residues of several metabolic hormones (Mersmann, 1998). The phosphorylation of hormone sensitive lipase activates the enzyme, resulting in the partial hydrolysis of TAG, whereas the phosphorylation of acetyl-CoA carboxylase inhibits de novo biosynthesis of fatty acids. Thus, the overriding

Feed Intake

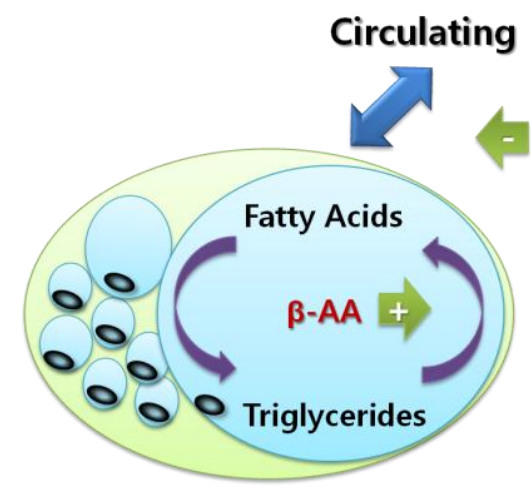

Adipose tissue

Energy Substrates

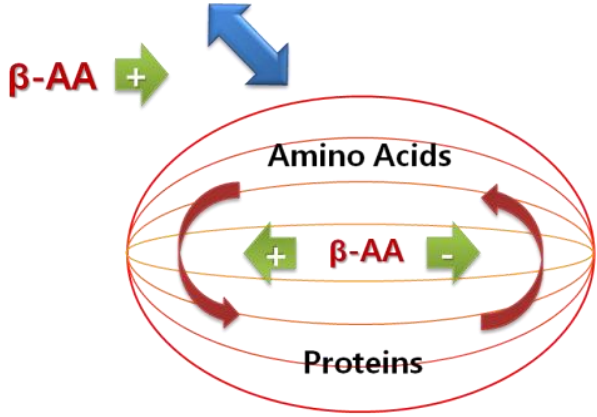

Muscle tissue

Figure 2. Proposed mechanisms of action by which $\beta$-adrenergic agonists decrease adiposity and increase muscle growth. Adapted from Ricks et al. (1984). 


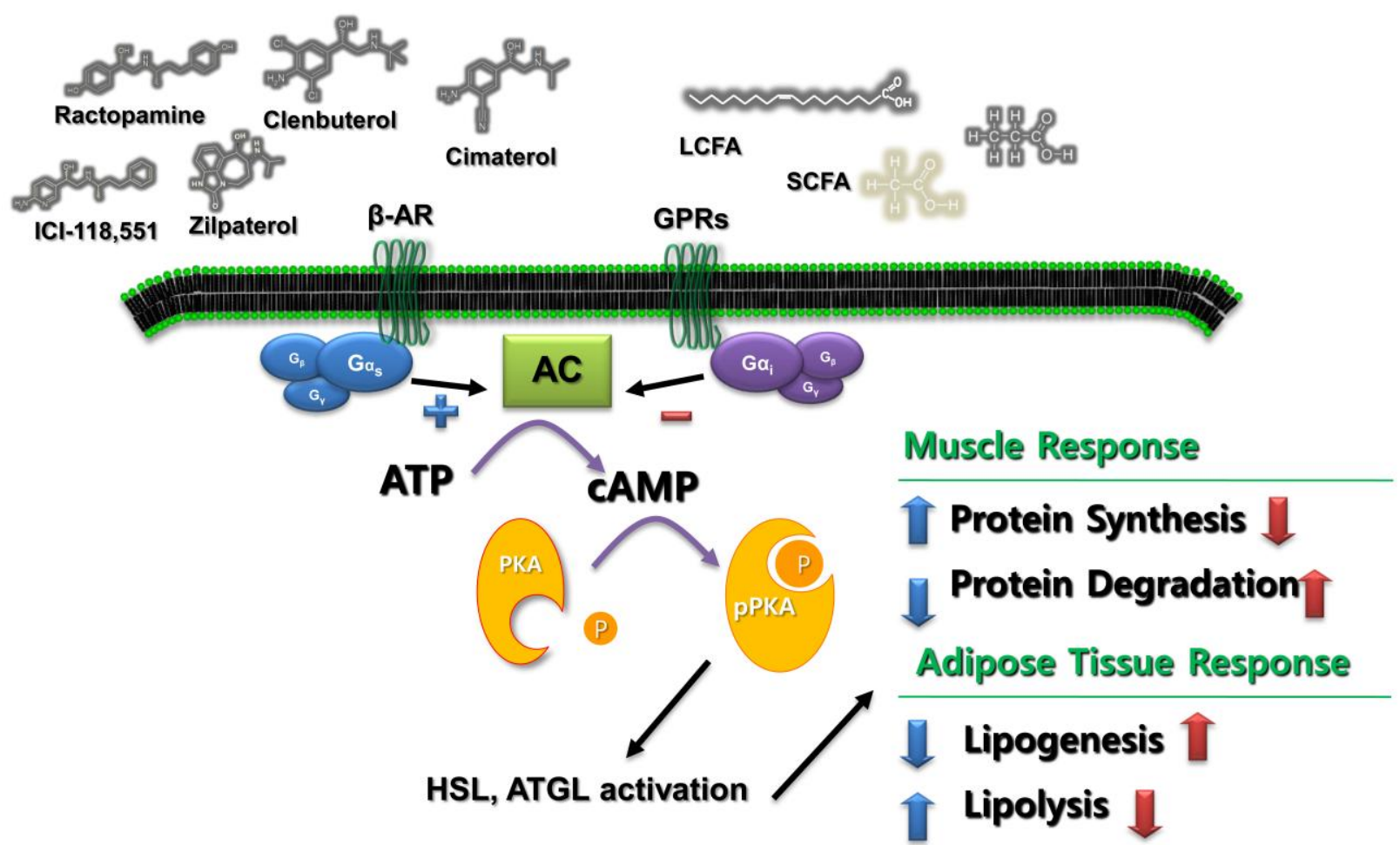

Figure 3. Interaction of proteins that mediate lipid mobilization from adipocytes. The first step in characterizing adrenergic agonists was to separate GPRs from $\beta$-ARs. While $\beta$-ARs regulate cell metabolism via $\mathrm{G}_{\mathrm{s}}$-protein stimulated cAMP-mediated events, GPRs oppose these effects because the GPR is coupled to the inhibitory $G_{i}$ protein. Beta AA activated protein synthesis through the cAMP signal cascade in the skeletal muscle. AC, adenylate cyclase; ATGL, adipose triglyceride lipase; ATP, adenosine triphosphate ; cAMP, cyclic adenosine monophosphate; GPR, G protein-coupled receptor; HSL, hormone-sensitive lipase; PKA, protein kinase A; TG, triacylglyerol.

biological response of adipose tissue to $\beta$-AA is a depression of TAG accumulation and concomitant release of fatty acids (Oscar, 1995).

Historically, the first step in characterizing adrenergic agonists was to separate $\alpha$-AR from $\beta$-AR (Sillence et al., 2005). Whereas $\beta$-AR regulate cell metabolism via $\mathrm{G}_{\mathrm{s}}-$ protein stimulated cAMP-mediated events, $\alpha$-AR oppose these effects because the $\alpha$-AR is coupled to the inhibitory $\mathrm{G}_{\mathrm{i}}$ protein (Figure 3). Epinephrine is the naturally occurring ligand for both the $\beta$-AR and $\alpha$ - $\mathrm{AR}$, so the net response to epinephrine will depend on the relative abundance of the two receptors. However, the $\alpha$-AR is not present in cell membranes of adipose tissue in livestock species, so this level of regulation is not essential to adipose tissue metabolism. After the initial demonstration of the $\beta$-AR, $\beta_{1^{-}}$ AR subtypes were distinguished from $\beta_{2}$-AR and $\beta_{3}$-AR subtypes. It has also been suggested that a fourth $\beta$-AR may exist in porcine adipose tissue (Sillence et al., 2005). Granneman et al. (2001) suggested that the putative $\beta_{4}$-AR could be a novel conformational state of the $\beta_{l}$-AR. In addition, no unique sequence has been determined for the hypothesized fourth $\beta$-receptor. This suggests that it may be a novel state of another receptor subtype rather than a unique subtype. All three $\beta$-AR subtypes $\left(\beta_{1}\right.$, Accession \#AF188187; $\beta_{2}$, Accession \#NM174231; $\beta_{3}$, Accession
\#X85961) have been cloned and sequenced for bovine. A summary of the distribution of the $\beta$-AR subtypes in several species and tissues is listed in Table 1 .

\section{RESPONSIVENESS OF BOVINE TISSUES TO $\beta$-ADRENERGIC AGONISTS}

The $\beta$-AR have been demonstrated in every cell type for every species investigated, but they differ widely in their

Table 1. Distribution of $\beta$-AR subtypes

\begin{tabular}{llc}
\hline Species & Tissue/organ & Abundance of $\beta$-AR subtype \\
\hline Rat & Heart & $>90 \% \beta_{1}$ \\
& Skeletal muscle, lung & $>85 \% \beta_{2}$ \\
& Adipose tissue & $>90 \% \beta_{3}$ \\
Pig & Heart & $>65 \% \beta_{1}$ \\
& Lung & $67 \% \beta_{1}$ \\
& Adipose tissue & $73 \% \beta_{1}, 20 \% \beta_{2}, 7 \% \beta_{3}$ \\
Human & Lung & $27 \% \beta_{1}$ \\
& Liver & $20 \% \beta_{1}$ \\
& Adipose tissue & $35 \% \beta_{1}, 65 \% \beta_{2}$ \\
Cattle & Skeletal muscle & $>99 \% \beta_{2}$ \\
& Adipose tissue & $>90 \% \beta_{2}$
\end{tabular}

$\beta$-AR, $\beta$-adrenergic receptors.

Mills and Mersmann, 1995; Mersmann, 1998. 
Table 2. Characterization of synthetic $\beta$-adrenergic agonists (AR) and antagonists in adipose tissues of rats, pigs, sheep, and cattle

\begin{tabular}{llc}
\hline Ligand & Species & $\beta$-AR subtype \\
\hline Agonists & & Partial $\beta_{3}$ \\
Propranolol & Human & Partial $\beta_{3}$ \\
& Cattle & Nonselective \\
Isoproterenol & All & Partial $\beta_{2}$ \\
Clenbuterol & Pigs & $\beta_{2}$ \\
& Rats/mice & $\beta_{2}$ \\
& Cattle & $\beta_{1} /$ partial $\beta_{2}$ \\
Ractopamine & Mice & $\beta_{1} /$ partial $\beta_{2}$ \\
& Pigs & $\beta_{3}$ \\
BRL37,344 & Rats & $\beta_{3}$ \\
CL316,243 & Rats & No effect \\
& Ewes & $\beta_{2}$ \\
L644,969 & Pigs & \\
Antagonists & & $\beta_{3}$ \\
Propranolol & Rats/mice & $\beta_{2}$ \\
BRL37,344 & Pigs & $\beta_{1}$ and $\beta_{2}$ \\
CGP12,177 & Calves & $\beta_{1}$ \\
CGP20,712A & Rats & $\beta_{1}$ \\
& Pigs & $\beta_{1}$ \\
ICI118,551 & Calves & $\beta_{2}$ \\
& Rats & No effect \\
& Pigs & $\beta_{2}$ \\
\hline & Calves &
\end{tabular}

Mills and Mersmann, 1995; Mersmann, 1998.

distribution and specificity for synthetic ligands (Table 2). CGP20,712 is a $\beta_{1}$-specific antagonist, whereas ICI118,551 is a specific antagonist for $\beta_{2}$-AR. Notably, ICI118,551 has no effect in pigs. BRL37,344 is a $\beta_{3}$-specific agonist in rodents, but is a $\beta_{2}$-agonist in pigs. CGP12,177 stimulates basal lipolysis in rat adipocytes, as well as inhibiting response to isoproterenol.

Previous studies have investigated the effect of $\beta_{2}$-AA on the individual muscle fiber level. Many of these studies assessed relative changes in both number as well as diameter of type I vs type II muscle fibers. Clenbuterol-fed heifers had greater type II muscle fiber diameters, but numerically type I muscle fiber diameters (Miller et al., 1988), relative to control heifers. Clenbuterol-fed steers also increased type IIA muscle fibers compared to control cattle (Smith et al., 1995). In addition, Kim et al. (1987) reported that in lambs fed cimaterol the proportion of type I to type II fibers in the longissimus and semitendinosus muscle were unaffected. However, the type II fibers had 50\% greater cross-sectional area in the longissimus and semitendinosus muscle of cimaterol-fed lambs compared to untreated lambs. However, cimaterol had no effect on the cross-sectional area of type I fibers (Kim et al., 1987). These data from both cattle and sheep suggested that $\beta_{2}$-AA can increase individual muscle fiber cross-sectional area. It is also apparent that type II fibers were the most responsive to the $\beta_{2}$-AA administration. In another study Beermann et al. (1987) reported that dramatic increases in hind-limb muscle mass of lambs fed cimaterol was a result of radial growth of both type I and type II fibers. In both of these studies, authors found a reduction in proportion of type I fibers compared to type II fibers due to cimaterol administration. Due to these findings, the authors concluded that hypertrophy of type II fibers contributed more to the cimaterol-induced increase in skeletal muscle mass compared to type I hypertrophy. However, cimaterol administration resulted in preferential increase in the number of type II fibers compared to type I fibers. Zilpaterol hydrochloride $(\mathrm{ZH})$, an orally active $\beta$-AA for finishing beef cattle, had no effect on $\beta_{l}$-AR mRNA levels, but there was an increase in $\beta_{2}$-AR mRNA levels (Baxa et al., 2010). Feeding of $\mathrm{ZH}$ the last $30 \mathrm{~d}$ prior to slaughter increased mRNA levels of myosin heavy chain-IIX (MHCIIX) in semimembranosus muscle but had no detectable effect on MHC-I and IIA mRNA levels. These data indicate that the change of mRNA concentration of MHC isoform and $\beta$-AR are correlated with skeletal muscle hypertrophy of beef cattle.

Park et al. (2009) indicated that the phosphorylation and subsequent activation of AMPK (Adenosine Monophosphates-activated Protein Kinase), a protein kinase involved in energy metabolism, is positively correlated with increasing mRNA levels of MHC IIX in pigs. This data reported that injection of an AMPK activator (AICAR) increased phosphorylation of AMPK and synergistically enhanced mRNA of MHC IIX without affecting MHC I or IIA mRNA levels. Because AMPK phosphorylation can be regulated by cAMP (Park et al., 2009), this data supports the theory that the cellular mechanism of postnatal muscle hypertrophy can be influenced by $\beta$-AA.

\section{THE $\beta$-ADRENERGIC AGONIST-STIMULATED MUSCLE HYPERTROPHY}

Many $\beta$-AA can be fed to ruminants and the effects of feeding a $\beta_{2}$-AA include the improvement of skeletal muscle mass and/or cross-sectional area of muscle fibers. Examples of these skeletal muscle-enhancing characteristics are summarized in Table 3.

Addition of either clenbuterol or cimaterol, both presumed $\beta_{2}-\mathrm{AA}$, to ruminants resulted in increased longissimus muscle (LM) cross-sectional area between $11 \%$ and $39 \%$. In addition, the mass of selected muscles was increased between $8 \%$ and $40 \%$. These data suggest that the addition of these $\beta_{2}$-AA to ruminants results in a dramatic increase in muscle mass. 
Table 3. Relative changes in individual muscle size and/or mass due to administration of a $\beta_{2}$-adrenergic agonist to ruminants

\begin{tabular}{llllll}
\hline Species & \multicolumn{1}{c}{$\beta_{2}$-agonist } & Dose & Muscle & $\%$ & Source \\
\hline Steers & Zilpaterol & $1.6 \mathrm{~g} / \mathrm{d}$ & Longissimus area & +10 & Choi et al., 2013 \\
Heifers & Zilpaterol & $7.3 \mathrm{mg} / \mathrm{kg} / \mathrm{d}$ & Longissimus area & - & Bloomberg et al., 2013 \\
Heifers & Zilpaterol & $8.3 \mathrm{mg} / \mathrm{kg} / \mathrm{d}$ & Longissimus area & +6.5 & Rathmann et al., 2011 \\
Steers & Zilpaterol & $8.3 \mathrm{mg} / \mathrm{kg} / \mathrm{d}$ & Longissimus area & +10 & Baxa et al., 2010 \\
Steers & Zilpaterol & $6 \mathrm{mg} / \mathrm{kg} / \mathrm{d}$ & Longissimus area & +10 & Montgomery et al., 2009 \\
Heifers & Zilpaterol & $0.15 \mathrm{mg} / \mathrm{kg}$ & Longissimus area & +6 & Robles-Estrada et al., 2009 \\
Steers & Zilpaterol & $60 \mathrm{mg} / \mathrm{hd} / \mathrm{d}$ & Longissimus area & +11 & Avendano-Reves et al., 2006 \\
Steers & Clenbuterol & $10 \mathrm{mg} / \mathrm{hd} / \mathrm{d}$ & Longissimus area & +11 & Ricks et al., 1984 \\
Steers & Clenbuterol & $500 \mathrm{mg} / \mathrm{hd} / \mathrm{d}$ & Longissimus area & +16 & Ricks et al., 1984 \\
Steers & Clenbuterol & $7 \mathrm{mg} / \mathrm{hd} / \mathrm{d}$ & Longissimus area & +28 & Shiavetta et al., 1990 \\
Steers & Clenbuterol & $7 \mathrm{mg} / \mathrm{hd} / \mathrm{d}$ & Longissimus weight & +25 & Shiavetta et al., 1990 \\
Steers & Clenbuterol & $10 \mathrm{mg} / \mathrm{hd} / \mathrm{d}$ & Longissimus area & +16 & Miller et al., 1988 \\
Steers & Clenbuterol & $10 \mathrm{mg} / \mathrm{hd} / \mathrm{d}$ & Longissimus weight & +8 & Miller et al., 1988 \\
Sheep & Cimaterol & $10 \mathrm{ppm}$ & Longissimus area & +39 & Kim et al., 1987 \\
Sheep & Cimaterol & $10 \mathrm{ppm}$ & Gastrocnemius weight & +40 & Kim et al., 1987 \\
Sheep & Cimaterol & $10 \mathrm{ppm}$ & Biceps femoris weight & +33 & Beermann et al., 1987 \\
Sheep & Cimaterol & $10 \mathrm{ppm}$ & Semimembranosus weight & +27 & Beermann et al., 1987 \\
Sheep & Cimaterol & $10 \mathrm{ppm}$ & Semitendinosus weight & +32 & Beermann et al., 1987 \\
Sheep & Cimaterol & $10 \mathrm{ppm}$ & Biceps femoris weight & +27 & O' Connor et al., 1991 \\
Sheep & Cimaterol & $10 \mathrm{ppm}$ & Semimembranosus weight & +30 & O' Connor et al., 1991 \\
Sheep & Cimaterol & $10 \mathrm{ppm}$ & Semitendinosus weight & +34 & O' Connor et al., 1991 \\
\hline & & & &
\end{tabular}

For $\beta$-AA to have direct effects on skeletal muscle hypertrophy, specific high-affinity receptors for the $\beta$-AA must be present on the surface of skeletal muscle cells. Previous research has reported the presence of both the mRNA for various subtypes of $\beta$-AR and specific binding sites for $\beta$-AA. Sillence et al. (1991) found that muscle homogenates from the beef LM contained predominately $\beta_{2}$-AR. Specifically, the sarcolemma membrane preparations of the LM were shown to bind to the $\left[{ }^{125} \mathrm{I}\right]$ ICYP radio ligand, a radioactive ligand that binds $\beta$-AR with binding affinities consistent with $\beta_{2}$-AR populations. In contrast, binding experiments revealed that there was no detectable $\beta_{1}$-AR present in these sarcolemma membrane preparations (Sillence et al., 1991). Subsequent research by this group (Sillence and Matthews, 1994) confirmed that $\beta_{1^{-}}$ AR could not be detected in bovine skeletal muscle and adipose tissue using classical ligand binding techniques. Other cell culture-related techniques have revealed that a very small population of $\beta_{1}$-AR is detectable in bovine tissues and are coupled to the production of the second messenger, cAMP.

Research from our laboratory, utilizing quantitative realtime PCR, has detected mRNA for all three $\beta$-AR subtypes in total RNA isolated from bovine longissimus and semimembranosus biopsy samples (Baxa et al., 2010). It is noteworthy that on the average $96 \%$ to $99 \%$ of the $\beta$-AR mRNA was identified as $\beta_{2}$ with the remaining $1 \%$ to $4 \%$ being $\beta_{1}$ and $\beta_{3}$ mRNA. The high abundance of $\beta_{2}$-AR
mRNA in bovine muscle tissue was consistent with ligand binding studies suggesting that greater than $90 \%$ of $\beta$-AR in bovine skeletal muscle.

\section{THE $\beta$-ADRENERGIC RECEPTOR INCREASES DURING PHYSIOLOGICAL GROWTH}

The presence of $\beta$-AR and distribution of different subtypes in skeletal muscle may be related to relative maturity of the animal. Minimal levels of $\beta$-AR were detected in multinucleated muscle cell cultures established from fetal bovine skeletal muscle as indicated by ligand binding studies. Additionally, short-term isoproterenol exposure did not increase cAMP production suggesting the lack of functional $\beta$-AR in fetal skeletal muscle (Bridge et al., 1998). However, small amounts of $\beta_{2}$-AR mRNA were present in total RNA from these cultures (Bridge et al., 1998). Studies feeding clenbuterol to both young and old rats suggested that older, more mature rats were more responsive to clenbuterol administration compared to younger rats (Greife et al., 1989). Clenbuterol feeding for $14 \mathrm{~d}$ to older, heavier (185 g) rats increased growth rate $11 \%$ compared to only a $22 \%$ increase in lighter (100 g), younger rats (Greife et al., 1989). The authors speculated that the disparate response was related to relative differences in body fat content. However, it also is possible that the increased density of $\beta$-AR in older rats could have mediated the improvements in growth rate. Similarly, field 
reports suggest older, heavier yearling cattle are more responsive to a $\beta$-AA compared to younger, immature calffed cattle. However, Schiavetta et al. (1990) fed $0.5 \mathrm{ppm}$ clenbuterol for $50 \mathrm{~d}$ to Angus steers beginning at $8 \mathrm{mo}$ of age and demonstrated the most profound effects of $\beta$-AA reported for any study involving livestock species. In their study, clenbuterol increased feed efficiency by $25 \%$ and increased LM mass by $24 \%$. Clenbuterol treatment also reduced marbling scores and carcass quality grades by onehalf grade (from Choice ${ }^{0}$ to Select ${ }^{+}$) and increased cooked beef shear force by over $1 \mathrm{~kg}$; the negative effects on carcass quality grade and beef tenderness persisted even after $78 \mathrm{~d}$ withdrawal from clenbuterol treatment (Schiavetta et al., 1990).

To further increase the understanding of the apparent age-dependent effects of $\beta$-AA administration on cattle growth, we determined the abundance of $\beta$-AR mRNA in muscle biopsies from calf-fed vs yearling-fed steers. Our preliminary data suggested that in yearling-fed steers, as days on feed increased, the abundance or $\beta_{l}$-AR mRNA decreased and the levels of $\beta_{2}$-AR mRNA significantly increased in skeletal muscle tissue (data not shown). In contrast, no change was detected in the mRNA levels of $\beta_{1^{-}}$ or $\beta_{2}$-AR in muscle biopsies from younger calf-fed steers. These data suggested that in older, heavier cattle, $\beta_{2}$-AR mRNA increased with advancing days on feed thus altering functional $\beta_{2}$-AR levels in skeletal muscle and ultimately may impact the responsiveness of skeletal muscle to $\beta$-AA.

In adipose tissue, isoproterenol (a selective $\beta$-AA agonist) has a strong lipolytic effect when infused through an i.v. in heifers (Ferlay and Chilliard, 1999) and lambs (Ferlay et al., 2001). Terbutaline, a $\beta_{2}$-AA, has a slight lipolytic effect when infused in heifers and lambs, whereas dobutamine, a $\beta_{1}$-AA, has no effect on lipolysis in heifers. The $\beta_{3}$-AA CL316,243 has no effect on lipolysis in ewes (Ferlay et al., 2001), consistent with the lack of functional brown adipose tissue in postnatal lambs (Smith et al., 2004; Smith and Carstens, 2005).

\section{PROTEIN SYNTHESIS IN SKELETAL MUSCLE}

The protein synthesis of porcine skeletal muscle has been shown to be enhanced by the treatment of ractopamine (Bergen et al., 1989). It has also been reported that ractopamine treatment of a myotube culture $\left(\mathrm{L}_{6}\right.$ cell culture model) increased myosin heavy-chain protein synthesis (Anderson et al., 1990). These data indicate that ractopamine induces muscle protein accretion and increased the myofibrillar and total protein synthesis. Treatment of ractopamine, a $\beta_{1}$-AA, did not change protein degradation in cultured $\mathrm{L}_{6}$ muscle cells (Anderson et al., 1990). Thus, this manuscript concluded that ractopamine-enhanced muscle protein accretion was due to increased protein synthesis with no detectable effect on protein degradation. Additionally, both ractopamine and clenbuterol have been shown to increase myosin light chain-1 (the Type II MLC-1 isoform) mRNA abundance in the LM of beef cattle compared to untreated cattle (Smith et al., 1989; Smith et al., 1995). Increasing myofibrillar protein synthesis likely is a result of $\beta$-AA-induced up-regulation of myofibrillar protein gene transcription. The increased mRNA transcription of muscle protein indicated an elevation in muscle hypertrophy. McMillan et al. (1992) reported that clenbuterol stimulated protein synthesis in murine primary culture system. These conclusions are further supported by muscle cell culture studies in which $\beta$-AA stimulated protein synthesis.

\section{PROTEIN TURNOVER IN SKELETAL MUSCLE}

An increase in myofibrillar protein degradation can decrease net protein accretion in skeletal muscle if not compensated by increased protein synthesis. The rate of protein degradation has been determined by differences between protein accretion and fractional synthesis (Beermann, 2002). The activities of calcium-dependent and lysosomal proteases and their inhibitors also have been determined following $\beta$-AA administration. Early studies indicated that muscle protein degradation is reduced or unaffected by $\beta$-AA administration. The majority of cattle work in the area of protein degradation has been conducted with the $\beta$-AA, L-644,969. This $\beta_{2}$-AA caused a $27 \%$ reduction in fractional protein degradation rate in steers compared to untreated controls (Wheeler and Koohmaraie, 1992). Additionally, the activity of a specific inhibitor to the calpains, calpastatin, was elevated in muscle samples of steers fed L-644,969 (Wheeler and Koohmaraie, 1992: Killefer and Koohmaraie, 1994). The treatment with $\beta$-AA has been reported to decrease overall meat tenderness in lambs (Hamby et al., 1986) and beef cattle (Miller et al., 1988; Schiavetta et al., 1990). The muscle proteases and inhibitors that regulate protein degradation that are affected in vivo often follow parallel responses in the postmortem meat. Schroeder et al. (2003) reported that $200 \mathrm{mg} \cdot \mathrm{hd}^{-1} \cdot \mathrm{d}^{-1}$ of ractopamine fed to steers and heifers had no effect on meat tenderness but $300 \mathrm{mg} \cdot \mathrm{hd}^{-1} \cdot \mathrm{d}^{-1}$ fed to steers increased shear force values compared to control samples. These data indicate that at higher doses ractopamine, a presumed $\beta_{1^{-}}$ $\mathrm{AA}$, can bind to $\beta_{2}$-AR and elicit a biological response consistent with that type of receptor.

It is possible that IGF-I could be mediating the increases in skeletal muscle hypertrophy due to increased protein synthesis and decreased protein degradation with $\beta$-AA. In lambs, cimaterol feeding (10 ppm) has been shown to 
reduce circulating IGF-I levels by $46.5 \%$ at $42 \mathrm{~d}$ and $21.5 \%$ at 84 d compared to untreated lambs (Beermann et al., 1987). Similarly, in more recent studies by Walker et al. (2006), ractopamine feeding to Holstein steers attenuated the $\mathrm{TBA} / \mathrm{E}_{2}$-induced increase in circulating IGF-I. Additionally, ractopamine feeding decreased LM IGF-I mRNA concentrations compared to concentrations observed before ractopamine feeding (Walker et al., 2006). Furthermore, IGF-I is known to stimulate the proliferative capacity of muscle satellite cells, which in turn supports postnatal muscle hypertrophy, although $\beta$-AA do not increase muscle DNA content. More research is needed to confirm the reduction in local and/or circulating IGF-I is related to the disconnect in satellite cell proliferation and fusion during $\beta$-AA stimulated skeletal muscle hypertrophy. The ability to circumvent these relationships could potentially sustain greater degrees of muscle hypertrophy following administration of $\beta$-AA.

\section{RACTOPAMINE AND ZILPATEROL AS A SPECIFIC $\beta$-ADRENERGIC AGONISTS}

The ZH has been used United States, South Africa, Mexico, and Canada for improving beef cattle growth and feed efficiency. The use of $\mathrm{ZH}$ in finishing diets improved average daily gain (ADG), weight gain, hot carcass weight (HCW), ribeye area, and dressing percentage (AvendanoReyes et al., 2006; Baxa et al., 2010; Vasconcelos et al., 2008). Although feeding $\mathrm{ZH}$ has less effects in heifers, $\mathrm{ZH}$ used in last 20 to $40 \mathrm{~d}$ before slaughter causes increased ADG, body weight (BW), gain to feed ratio (G:F), and HCW in steers and heifers (Montgomery et al., 2009).

Zilpaterol (Figure 4) is strikingly different in terms of its structure compared to other $\beta_{2}$-AA like ractopamine, clenbuterol or cimaterol. The structures of clenbuterol and cimaterol are very similar to norepinephrine and epinephrine. Recent results indicated that $\mathrm{ZH}$ binds with high affinity to $\beta_{2}$ - $\mathrm{AR}$, but the binding affinity of $\mathrm{ZH}$ to $\beta_{2^{-}}$ AR was lower as compared to clenbuterol $\left(10^{-6} M\right.$ vs $10^{-8}$ $M)$. Additionally, the binding of $\mathrm{ZH}$ to $\beta_{1}$-AR was weaker than its binding affinity to $\beta_{2}$-AR (Verhoeckx et al., 2005). Subsequent work has confirmed these results and extended their understanding by showing that $\mathrm{ZH}$, acting through a
$\beta_{2}$-AR, increased cAMP levels in cultured U937 macrophages (Verhoeckx et al., 2006).

\section{PRACTICAL CONSIDERATIONS}

The maximal response of $\beta$-AA is affected by the dose and duration of a sustained dose (e.g., in its effects on MLC-1 gene expression; Smith et al., 1989). It has been well documented that the $\beta$-AR-mediated increase in cAMP is transient and that continuous receptor activation by the $\beta$-AA ligand is necessary to maintain the cAMP levels to sustain the response. Exposure to a constant dose of $\beta$-AA to the receptor will eventually cause acute desensitization or inactivation of receptor-mediated signaling. The phosphorylation of both protein kinase $\mathrm{A}$ and $\beta$-AR kinases are the main steps in initiating the signaling cascade following $\beta$-AR activation of cAMP (Hausdorff et al., 1990). Acute desensitization can be circumvented to some degree by increasing the dose and potentiating the signal. Longterm exposure (chronic) at elevated doses of $\beta$-AA leads to internalization or loss of the receptor from the cell surface and down-regulation in $\beta$-AR mRNA abundance (Hausdorff et al., 1990). These alterations appear to be irreversible at least in the short-term feeding period.

\section{SAFETY CONSIDERATIONS WITH UNAPPROVED- $\beta$-ADRENERGIC AGONISTS}

Both clenbuterol and salbutamol are presumed $\beta_{2}$-AA that have been studied as growth promotants in many species including beef cattle. The biological effects of clenbuterol in beef cattle were first described by Ricks et al. (1984). Clenbuterol is chemically described as a benzyl alcohol, 4 amino-alpha-(tbutylamino)methyl-3,5-dichloro. Earlier research studies have indicated that clenbuterol was a very potent $\beta_{2}$-AA in cattle. Very little information is available in the scientific literature in regards to salbutamol.

Neither clenbuterol nor salbutamol is approved for use in meat animal production in the USA. The pharmaceutical company, American Cyanamid, abandoned the approval process for clenbuterol in the early 1990s when it appeared there may be a residue toxicity issue with clenbuterol in certain edible tissues of beef. Clenbuterol received much

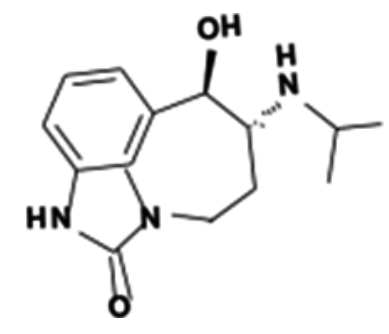<smiles>C[C@H](CCc1ccc(O)cc1)NC[C@@H](O)c1ccc(O)cc1</smiles>

Figure 4. Structure of Zilpaterol (RU 42173) and Ractopamine. 
negative attention in the early 1990s when its illegal feeding to cattle resulted to cases of food poisoning in both Spain and France (Martinez-Navarro, 1990; Salleras et al., 1995). Individuals consuming liver from animals illegally-fed clenbuterol possessed symptoms of tachycardia, tremors, headache, and dizziness.

Indiscriminate use of clenbuterol and other nonapproved $\beta_{2}$-AA such as salbutamol continue to be a major issue across the globe. Individuals who illegally feed these agents to cattle often do so at rates much greater than were ever tested in research trials. This can result in residue levels in both the kidneys and liver at levels great enough to cause food poisoning. Research by Smith and Paulson (1997) revealed that clenbuterol residues were greatest in lung, kidney, and liver in cattle fed $3 \mathrm{mg} / \mathrm{kg}$ ( $3 \mathrm{ppm}$ ) BW of clenbuterol. These concentrations averaged $8.36 \mathrm{ppm}$ in lung tissue, $5.9 \mathrm{ppm}$ in kidney, and $5.04 \mathrm{ppm}$ in liver. It has been suggested that the effective oral dose of clenbuterol in humans can be as low as $10 \mu \mathrm{g} / \mathrm{d}$. Levels above this could begin to cause food poisonings. At a residue of $5 \mathrm{ppm}$, an individual would only need to consume $2 \mathrm{~g}$ to equal the effective dose in humans. Due to these human health concerns, clenbuterol and other potent $\beta_{2}$-AA will most likely never be approved for use in meat-animal production.

The two $\beta$-AA that have been approved for use in the $\mathrm{U}$. $S$. and other countries around the globe, ractopamine and $\mathrm{ZH}$, have been studied extensively from a residue standpoint. When fed at the approved dose and label directions are followed for withdrawal times, negligible to undetectable levels of residues have been reported. For example, $\mathrm{ZH}$ feeding at the normal approved dose resulted in liver and kidney residue levels of 0.18 and $0.09 \mathrm{ppm}$ after a $48 \mathrm{~h}$ withdrawal (Zilmax FOI Summary, NADA 141-258, August, 2006). These absolute concentrations are much less than those reported for clenbuterol. Additionally, the effective oral dose of $\mathrm{ZH}$ in humans is much higher than that reported for clenbuterol. Taken together, these data indicate that there are key differences in the metabolism, excretion and activity of different $\beta$-AA.

\section{CONCLUSIONS}

As indicated in this review, $\beta$-AA consistently improve beef cattle performance and increase muscle growth when mixed with finishing rations. The $\beta$-AA increase ADG, G:F, $\mathrm{HCW}$, LM cross-sectional area and mass, and dressing percentage. However, cattle receiving $\beta$-AA tend to have a reduced marbling scores, lower back-fat thickness and increased beef toughness. Elevation of glycolytic fiber types with $\beta$-AA treatment is primarily responsible for the increased muscle hypertrophy but otherwise is negatively correlated with both intermuscular and intramuscular adipose tissue amount. Further study is needed to find methods to enhance growth performance without reducing beef quality in $\beta$-AA-treated cattle.

\section{ACKNOWLEDGMENTS}

This work was carried out with the support of "Cooperative Research Program for Agriculture Science \& Technology Development (Project No. PJ009414 )" Rural Development Administration, Republic of Korea.

\section{REFERENCES}

Anderson, P. T., W. G. Helferich, L. C. Parkhill, R. A. Merkel, and W. G. Bergen. 1990. Ractopamine increases total and myofibrillar protein synthesis in cultured rat myotubes. J. Nutr. 120:1677-1683.

Avenano-Reyes, L., V. Torres-Rodriguez, F. J. Meraz-Murillo, C. Perez-Linares, F. Figueroa-Saavedra, and P. H. Robinson. 2006. Effects of two $\beta$-adrenergic agonists on finishing performance, carcass characteristics, and meat quality of feedlot steers. J. Anim. Sci. 84:3259-3265.

Baxa, T. J., J. P. Hucheson, M. F. Miller, J. C. Brooks, W. T. Nichols, M. N. Streeter, D. A. Yates, and B. J. Johnson. 2010. Additive effects of a steroidal implant and zilpaterol hydrochloride on feedlot performance, carcass characteristics, and skeletal muscle messenger ribonucleic acid abundance in finishing steers. J. Anim. Sci. 88:330-337.

Beermann, D. H., W. R. Butler, D. E. Hogue, V. K. Fishell, R. H. Dalrymple, C. A. Ricks, and C. G. Scanes. 1987. Cimaterolinduced muscle hypertrophy and altered endocrine status in lambs. J. Anim. Sci. 65:1514-1524.

Beermann, D. H. 2002. Beta-Adrenergic receptor agonist modulation of skeletal muscle growth. J. Anim. Sci. 80:E18E23.

Beckett, J. L., R. J. Delmore, G. C. Duff, D. A. Yates, D. M. Allen, T. E. Lawrence, and N. Elam. 2009. Effects of zilpaterol hydrochloride on growth rates, feed conversion, and carcass traits in calf-fed Holstein steers. J. Anim. Sci 87:4092-4100.

Bergen, W. G., S. E. Johnson, D. M. Skjaerlund, A. S. Babiker, N. K. Ames, R. A. Merkel, and D. B. Anderson. 1989. Muscle protein metabolism in finishing pigs fed ractopamine. J. Anim. Sci. 67:2255-2262.

Bischoff, R. 1986. A satellite cell mitogen from crushed adult muscle. Dev. Biol. 115:140-147.

Bloomberg, B. D., G. G. Mafi, B. J. Pye, J. L. Richards, J. B. Morgan, and D. L. Vanoverbeke. 2013. Impact of helth management, health treatments, and zilpaterol hydrochloride supplementation on carcass quality, color, and palatability traits in heifers. J. Anim. Sci. 91:3465-3473.

Branaman, G. A., A. M. Pearson, W. T. Magee, R. M. Griswold, and G. A. Brown. 1962. Comparison of the cutability and etaability of beef- and dairy- type cattle. J. Anim. Sci. 21:321326.

Bridge, K. Y., C. K. Smith, II, and R. B. Young. 1998. Betaadrenergic receptor gene expression in bovine skeletal muscle cells in culture. J. Anim. Sci. 76:2382-2391. 
Choi, C. B., K. K. Jung, K. Y. Chung, B. S. Yang, K. B. Chin, S. W. Suh, D. H. Oh, M. S. Jeon, K. H. Baek, S. O. Lee, S. I. Kim, Y. H. Lee, D. A. Yates, J. P. Hutcheson, and B. J. Johnson. 2013. Administration of zilpaterol hydrochloride alters feedlot performance, carcass characteristics, muscle, and fat profiling in finishing Hanwoo steers. Livest. Sci. 157:435-441.

Ferlay, A., C. Charret, J. Galitzky, M. Berlan, and Y. Chilliard. 2001. Effects of the perfusion of $\beta-, \beta 2$-, or $\beta 3$-adrenergic agonists or epinephrine on in situ adipose tissue lipolysis measured by microdialysis in underfed ewes. J. Anim. Sci. 79:453-462.

Ferlay, A. and Y. Chilliard. 1999. Effects of the infusion of nonselective $\beta$-, and selective $\beta_{1^{-}}$or $\beta_{2}$-adrenergic agonists, on body fat mobilisation in underfed or overfed non-pregnant heifers. Reprod. Nutr. Dev. 39:409-421.

Greife, H. A., G. Klotz, and F. Berschauer. 1989. Effects of the phenethanolamine clenbuterol on protein and lipid metabolism in growing rats. J. Anim. Physiol. Anim. Nutr. 61:19-27.

Granneman, J. G. 2001. The putative beta4-adrenergic receptor is a novel state of the beta1-adrenergic receptor. Am. J. Physiol, Endocrinol. Metab. 280:E199-202.

Hamby, P. L., J. R. Stouffer, and S. B. Smith. 1986. Muscle metabolism and real-time ultrasound measurement of muscle and subcutaneous adipose tissue growth in lambs fed diets containing a beta-agonist. J. Anim. Sci. 63:1410-1417.

Hausdorff, W. P., M. J. Lohse, M. Bouvier, S. B. Liggett, M. G. Caron, and R. J. Lefkowitz. 1990. Two kinases mediate agonist-dependent phosphorylation and desensitization of the beta 2-adrenergic receptor. Symp. Soc. Exp. Biol. 44:225-240.

Kim, Y. S., Y. B. Lee, and R. H. Dalrymple. 1987. Effect of the repartitioning agent cimaterol on growth, carcass and skeletal muscle characteristics in lambs. J. Anim. Sci. 65:1392-1399.

Martinez-Navarro, J. F. 1990 Food poisoning related to consumption of illicit beta-agonist in liver. Lancet 336:1311.

McMillan, D. N., B. S. Noble, and C. A. Maltin. 1992. The effect of the beta-adrenergic agonist clenbuterol on growth and protein metabolism in rat muscle cell cultures. J. Anim. Sci. 70:3014-3023

Mersmann, H. J. 1998. Overview of the effects of ß-adrenergic receptor agonists on animal growth including mechanisms of action. J. Anim. Sci. 76:160-172.

Mersmann, H. J. and S. B. Smith. 2005. Development of white adipose tissue lipid metabolism. In: Biology of Metabolism in Growing Animals (Eds. D. G. Burrin and H. J. Mersmann). Elsevier Science Publishers, Oxford, UK. pp. 275-302.

Mills, S. E. and H. J. Mersmann. 1995. Beta-adrenergic agonists, their receptors, and growth: Special reference to the peculiarities in pigs. In: Biology of Fat in Meat Animals: Current Advances (Eds. S. B. Smith and D. R. Smith). pp 1-34. American Society of Animal Science, Champaign, IL, USA.

Miller, M. F., D. K. Garcia, M. E. Coleman, P. A. Ekeren, D. K. Lunt, K. A. Wagner, M. Prochnor, T. H. Welsh, Jr., and S. B. Smith. 1988. Adipose tissue, longissimus muscle and anterior pituitary growth and function in clenbuterol-fed heifers. J. Anim. Sci. 66:12-20.

McMillan, D. N., B. S. Noble, and C. A. Maltin. 1992. The effect of the $\beta$-adrenergic agonist clenbuterol on growth and protein metabolism in rat muscle cell cultures. J. Anim. Sci. 70:30143023.
Montgomery, J. L., C. R. Krehbiel, J. J. Cranston, D. A. Yates, J. P. Hutcheson, W. T. Nichols, M. N. Streeter, R. S. Swingle, and T. H. Montgomery. 2009. Effects of dietary zilpaterol hydrochloride on feedlot performance and carcass characteristics of beef steers fed with and without monensin and tylosin. J. Anim. Sci. 87:1013-1023.

Martinez-Navarro, J. F. 1990. Food poisoning related to the consumption of illicit $\beta$-agonist in liver. Lancet 336:1311.

Killefer, J. and M. Koohmaraie. 1994. Bovine skeletal muscle calpastatin: Cloning, sequence analysis and steady-state mRNA expression. J. Anim. Sci. 72:606-614.

Kim, Y. S., Y. B. Lee, and R. H. Dalrymple. 1987. Effect of the repartitioning agent cimaterol on growth, carcass and skeletal muscle characteristics in lambs. J. Anim. Sci. 65:1392-1399.

O'Connor, R. M., W. R. Butler, K. D. Finnerty, D. E. Hogue, and D. H. Beermann. 1991. Temporal pattern of skeletal muscle changes in lambs fed cimaterol. Domest. Anim. Endocrinol. 8:549-554.

Oscar, T. P. 1995. Lipid mobilization from chicken fat cells. In: Biology of Fat in Meat Animals: Current Advances (Eds. S. B. Smith and D. R. Smith). American Society of Animal Science, Champaign, IL, USA. pp. 93-112.

Park, S. K., T. L. Sheffler, M. E. Spurlock, A. L. Grant, and D. E. Gerrard. 2009. Chronic activation of 5'-AMP-activated protein kinase changes myosin heavy chain expression in growing pigs. J. Anim. Sci. 87:3124-3133.

Rathmann, R. J., B. C. Bernhard, R. S. Swingle, T. E. Lawrence, W. T. Nichols, D. A. Yates, J. P. Hurcheson, M. N. Streeter, J. C. Brooks, M. F. Miller, and B. J. Johnson. 2012. Effect of zilpaterol hydrochloride and days on the finishing diet on feedlot performance, carcass characteristics, and tenderness in beef heifers. J. Anim. Sci. 90:3301-3311.

Ricks, C. A., R. H. Dalrymple, P. K. Baker, and D. L. Ingle. 1984. Use of a $\beta$-agonist to alter fat and muscle deposition in steers. J. Anim. Sci. 59:1247-1255.

Salleras, L., A. Dominguez, E. Mata, J. L. Taberner, I Moro, and P. Salva. 1995. Epidemiologic study of an outbreak of clenbuterol poisoning in Catalonia, Spain. Public Health Rep. 110:338-342.

Schiavetta, A. M., M. F. Miller, D. K. Lunt, S. K. Davis, and S. B. Smith. 1990. Adipose tissue cellularity and muscle growth in young steers fed the beta-adrenergic agonist clenbuterol for 50 days and after 78 days of withdrawal. J. Anim. Sci. 68:36143623.

Schroeder, A. L., D. M. Polser, S. B. Laudert, and G. J. Vogel. 2003. The effect of Optaflexx on growth performance and carcass traits of steers and heifers. Optaflexx ${ }^{\mathrm{TM}}$ Exchange No. 1-3.

Sillence, M. N., J. Hooper, G. H. Zhou, Q. Liu, and K. J. Munn. 2005. Characterization of porcine $\beta_{1^{-}}$and $\beta_{2}$-adrenergic receptors in heart, skeletal muscle, and adipose tissue, and the identification of an atypical $\beta$-adrenergic binding site. J. Anim. Sci. 83:2339-2348.

Sillence, M. N. and M. L. Matthews. 1994. Classical and atypical binding sites for beta-adrenergic ligands and activation of adenylyl cyclase in bovine skeletal muscle and adipose tissue membranes. Br. J. Pharmacol. 111:866-872.

Sillence, M. N., G. G. Pegg, and D. B. Lindsay. 1991. Affinity of clenbuterol analogues for $\beta_{2}$-adrenoceptors in bovine skeletal 
muscle and the effect of these compounds on urinary nitrogen excretion in female rats. Arch. Pharmacol. 344:442-448.

Smith, D. J. and G. D. Paulson. 1997. Distribution, elimination, and residues of $[14 \mathrm{C}]$ clenbuterol HCL in Holstein calves. J. Anim. Sci. 75:454-461.

Smith, S. B., S. K. Davis, J. J. Wilson, R. T. Stone, F. Y. Wu, D. K. Garcia, D. K. Lunt, and A. M. Schiavetta. 1995. Bovine fasttwitch myosin light chain 1: cloning and mRNA amount in muscle of cattle treated with clenbuterol. Am. J. Physiol. 268:E858-865.

Smith, S. B., G. E. Carstens, R. D. Randel, H. J. Mersmann, and D. K. Lunt. 2004. Brown adipose tissue development and metabolism in ruminants. J. Anim. Sci. 82:942-954.

Smith, S. B. and G. E. Carstens. 2005. Ontogeny and metabolism of brown adipose tissue in livestock species. In: Biology of Metabolism in Growing Animals (Eds. D. G. Burrin and H. J. Mersmann). Elsevier Science Publishers, Oxford, UK. pp. 303322.

Strydom, P. E., L. Frylinck, J. L. Montgomery, and M. F. Smith. 2009. The comparison of three $\beta$-agonists for growth performance carcass characteristics and meat quality of feedlot cattle. Meat Sci. 81:557-564.

Vann, R. A., T. G. Althen, W. K. Smith, J. J. Veenhuizen, and S. B. Smith. 1998. Recombinant bovine somatotropin (rBST) administration to creep-fed beef calves increases muscle mass but does not affect satellite cell number or concentration of MLC-1f mRNA. J. Anim. Sci. 76:1371-1379.
Vasconcelos, J. T., R. J. Rathmann, R. R. Reuter, J. Leibovich, J. P. McMeniman, K. E. Hales, T. L. Covey, M. F. Miller, W. T. Nichols, and M. L. Galyean. 2008. Effects of duration of zilpaterol hydrochloride feeding and days on the finishing diet on feedlot cattle performance and carcass traits. J. Anim. Sci. 86:2005-2015.

Verhoeckx, K. C. M., R. P. Doornbos, J. van der Greef, R. F. Witkamp, and R. J. T. Rodenberg. 2005. Inhibitory effects of the $\beta_{2}$-adrenergic receptor agonist zilpaterol on the LPSinduced production of TNF- $\alpha$ in vitro and in vivo. J. Vet. Pharmacol. Ther. 28:531-537.

Verhoeckx, K. C. M., R. P. Doornbos, R. F. Witkamp, J. van der Greef, and R. J. T. Rodenberg. 2006. Beta-adrenergic receptor agonists induce the release of granulocyte chemotactic protein2 , oncostatin $\mathrm{M}$, and vascular endothelial growth factor from macrophages. Int. Immunopharmacol. 6:1-7.

Walker, D. K., E. C. Titgemeyer, J. S. Drouillard, E. R. Loe, B. E. Depenbusch, and A. S. Webb. 2006. Effects of ractopamine and protein source on growth performance and carcass characteristics of feedlot heifers. J. Anim. Sci. 84:2795-2800.

Walker, D. K., E. C. Titgemeyer, T. J. Baxa, K. Y. Chung, D. E. Johnson, S. B. Laudert, and B. J. Johnson. 2010. Effects of ractopamine and sex on serum metabolites and skeletal muscle gene expression in finishing steers and heifers. J. Anim. Sci. 88:1349-1357.

Wheeler, T. L. and M. Koohmaraie. 1992. Effects of the betaadrenergic agonist L-644,969 on muscle protein turnover, endogenous proteinase activities and meat tenderness in steers. J. Anim. Sci. 70:3035-3043. 